Journal of Asian Natural Products Research

\title{
Phenolic Compounds from Eurycorymbus cavaleriei
}

Yi He ${ }^{\text {a,b }}$, Li Zhang ${ }^{c}$, Ming Zhao ${ }^{\text {a }}$, Sam-Hip Tsai ${ }^{\mathrm{a}}$, Yuying Zong ${ }^{\mathrm{a}}$, and Chun-Tao $\mathrm{Che}^{\mathrm{a}, \mathrm{d} *}$

${ }^{a}$ School of Chinese Medicine, The Chinese University of Hong Kong, Hong Kong; ${ }^{b}$ National Institutes for Food and Drug Control, Beijing 100050, P. R. China; ${ }^{c}$ Institute of Materia Medica, Chinese Academy of Medical Sciences \& Peking Union Medical College, Beijing 100050, P. R. China; ${ }^{d}$ Department of Medicinal Chemistry and Pharmacognosy, College of Pharmacy, The University of Illinois at Chicago, Chicago, IL 60612, U.S.A.

${ }^{*}$ Corresponding author. E-mail: chect@cuhk.edu.hk 
Three new phenolic compounds, eurycorymboside A (1), eurycorymboside B (6), and eurycorymbic acid (8) were isolated from the stem part of Eurycorymbus cavaleriei (Sapindaceae), along with five known phenolic compounds, glucosyringic acid (2), vanillic acid 4-O- $\beta$-D-glucoside (3), koaburaside (4), tachioside (5), and 4-hydroxy-3,5-bis(3-methyl-2-butenyl)benzaldehyde (7). The structures were established on the basis of spectral analysis. The antioxidant activities of the compounds 1-6 were evaluated by the DPPH free radical scavenging assay. Compound 4 exhibited antioxidant activity with an $\mathrm{IC}_{50}$ value of $9.0 \mu \mathrm{M}$. Compound 4 also showed weak inhibitory activity against influenza A neuraminidase.

Keywords: Eurycorymbus cavaleriei; Sapindaceae; Phenolic compound 


\section{Introduction.}

Eurycorymbus cavaleriei (Levl.) Rehd. et Hand.-Mazz. is the only species of the genus Eurycorymbus (Sapindaceae). The plant is endemic in the southern regions of China including Hunan, Yunnan, Sichuan, Guangxi, and Guangdong provinces [1]. Previous phytochemical investigations on this plant have resulted in the isolation of lignan, coumarin, coumarinolignoid, meroterpene, benzeneacetic acid derivative, and flavone compounds [2-6]. Our continuing phytochemical and pharmacological investigation of this plant led to the isolation of eight phenolic compounds, including three new compounds. In this paper, we describe the isolation and structure identification of the three new phenolic compounds, 1, 6, and 8 (Figure 1), and the evaluation of antioxidant and neuraminidase inhibitory activities of compounds 1-6.

\section{Results and discussion.}

Compound 1 was obtained as a white amorphous powder. Its atmospheric pressure chemical ionization (APCI) mass spectrum displayed a quasi-molecular ion at $\mathrm{m} / \mathrm{z}$ $344\left[\mathrm{M}+\mathrm{NH}_{4}\right]^{+}$in positive mode, consistent with the formula $\mathrm{C}_{15} \mathrm{H}_{18} \mathrm{O}_{8}$, which was supported by HR-electrospray ionization (ESI)-MS (m/z 349.0900 [M+Na] $]^{+}$; calcd for $\left.\mathrm{C}_{15} \mathrm{H}_{18} \mathrm{O}_{8} \mathrm{Na}, 349.0894\right)$. The ${ }^{1} \mathrm{H}-\mathrm{NMR}$ signals at $\delta 7.32(2 \mathrm{H}, \mathrm{d}, J=9.0 \mathrm{~Hz}, \mathrm{H}-2$ and $\mathrm{H}-6)$ and $7.02(2 \mathrm{H}, \mathrm{d}, J=9.0 \mathrm{~Hz}, \mathrm{H}-3$ and $\mathrm{H}-5)$ suggested the presence of a para-substituted phenyl moiety; while the ${ }^{13} \mathrm{C}-\mathrm{NMR}$ signal at $\delta 170.3(\mathrm{C}-8)$ is attributed to a carbonyl group. The ${ }^{1} \mathrm{H}-$ and ${ }^{13} \mathrm{C}-\mathrm{NMR}$ spectra also revealed the presence of a $\beta$-glucose moiety. The HMQC spectrum showed the correlations between two protons at $\delta 6.19$ and 5.81 to a carbon at $\delta 125.8(\mathrm{C}-9)$, indicating that this carbon was an unsaturated secondary carbon. In the HMBC spectrum (Figure 2), the two methylene proton signals at $\delta 6.19$ and $5.81(\mathrm{H}-9 \mathrm{a}, 9 \mathrm{~b})$ displayed correlations with a quaternary carbon at $\delta 142.7(\mathrm{C}-7)$, the carboxylic carbon at $\delta 170.3(\mathrm{C}-8)$, and an aromatic carbon at $\delta 132.4(\mathrm{C}-1)$, suggesting the presence of an acrylic acid moiety on the phenolic ring. On the other hand, the anomeric proton of glucose $(\delta$ 4.87) exhibited long-range correlation with C-4 ( $\delta$ 159.0) suggesting that C-4 was 
glucosylated. On the basis of the above findings, the structure of $\mathbf{1}$ was established as depicted in Fig. 1 and given a trivial name of eurycorymboside A.

Compound 6 was obtained as an amorphous powder. The APCI-MS ( $\mathrm{m} / z 464$ $\left[\mathrm{M}+\mathrm{NH}_{4}\right]^{+}, 447[\mathrm{M}+\mathrm{H}]^{+}$) was consistent with the formula $\mathrm{C}_{19} \mathrm{H}_{26} \mathrm{O}_{12}$, which was supported by HR-ESI-MS (m/z $469.1319[\mathrm{M}+\mathrm{Na}]^{+}$; calcd for $\mathrm{C}_{19} \mathrm{H}_{26} \mathrm{O}_{12} \mathrm{Na}$, 469.1316). The ${ }^{1} \mathrm{H}-\mathrm{NMR}$ signals at $\delta 6.68(1 \mathrm{H}, \mathrm{d}, J=3.0 \mathrm{~Hz}, \mathrm{H}-2), 6.65(1 \mathrm{H}, \mathrm{d}, J=8.4$ $\mathrm{Hz}, \mathrm{H}-5)$, and $6.51(1 \mathrm{H}, \mathrm{dd}, J=3.0,8.4 \mathrm{~Hz}, \mathrm{H}-6)$ suggested the presence of a 1,3,4-trisubstituted phenyl moiety. Its ${ }^{1} \mathrm{H}-\mathrm{NMR}$ spectrum was similar to that of tachioside (5) except for the signals due to the sugar moiety, two methylenes, and a methyl group. The ${ }^{13} \mathrm{C}$-NMR spectra showed 19 carbon signals, with seven aglycone carbon signals similar to that of 5 , six sugar carbon signals $\left(\delta_{\mathrm{C}} 64.6,71.5,74.9,75.3\right.$, 77.8, and 103.7), two carbonyl carbons ( $\delta_{\mathrm{C}} 172.4$ and 174.8), two methylene carbons $\left(\delta_{\mathrm{C}} 45.8\right.$ and 46.3$)$, one methyl carbon $\left(\delta_{\mathrm{C}} 27.7\right)$, and one saturated quaternary carbon $\left(\delta_{\mathrm{C}}\right.$ 70.7), those data suggested that compound $\mathbf{6}$ is composed of $\mathbf{5}$ and 3-hydroxy-3-methyl-glutaric acid (HMGA). In HMBC spectrum (Figure 2), the proton signals at $\delta 4.43$ and 4.15 (H-6'a, 6'b) displayed correlations with the carboxylic carbon at $\delta 172.4$ (C-1'), suggesting the HMGA is substituted at the C-6' position by an ester bond. Thus, the structure of compound $\mathbf{6}$ was determined as depicted in Fig. 1 and given a trivial name eurycorymboside B.

Compound 8 was obtained as a white amorphous powder. The molecular formula was determined to be $\mathrm{C}_{20} \mathrm{H}_{28} \mathrm{O}_{4}$ by the negative HR-ESI-MS $(m / z 331.1994$ [M-H]; calcd for $\mathrm{C}_{20} \mathrm{H}_{27} \mathrm{O}_{4}, 331.1988$ ). The characteristic fragment ion peaks at $\mathrm{m} / z 287$ $\left[\mathrm{M}-\mathrm{CH}_{3} \mathrm{CH}_{2} \mathrm{OH}+\mathrm{H}\right]^{+}$of positive APCI-MS suggested the existence of an ethoxy group which was also supported by the negative HR-ESI-MS $(\mathrm{m} / \mathrm{z} 286.1576$ [M- $\left.\mathrm{CH}_{3} \mathrm{CH}_{2} \mathrm{OH}\right]^{-}$; calcd for $\left.\mathrm{C}_{18} \mathrm{H}_{21} \mathrm{O}_{3}, 286.1569\right)$.

The ${ }^{1} \mathrm{H}-\mathrm{NMR}$ spectrum showed proton signals of a 1,3,4,5-tetrasubstituted benzene ring $[\delta 7.02(2 \mathrm{H}, \mathrm{s}, \mathrm{H}-2,6)]$, one oxygenated methenyl $[\delta 4.76(1 \mathrm{H}, \mathrm{s}, \mathrm{H}-7)]$, one ethoxy $[\delta 3.55(2 \mathrm{H}, \mathrm{m}, \mathrm{H}-9)$ and $1.27(3 \mathrm{H}, \mathrm{t}, J=6.4 \mathrm{~Hz}, \mathrm{H}-10)]$, two olefins $[\delta 5.30$ $\left(2 \mathrm{H}, \mathrm{m}, \mathrm{H}-2^{\prime}, 2\right.$ '")], and four methyls $\left[\delta 1.18\left(12 \mathrm{H}, \mathrm{s}, \mathrm{H}-4^{\prime}, 5^{\prime}, 44^{\prime}, 5^{\prime \prime}\right)\right]$, which revealed 
the symmetrical structure of 8 . The ${ }^{13} \mathrm{C}-\mathrm{NMR}$ spectrum showed 13 carbon resonances including one carbonyl resonance at $\delta_{\mathrm{C}} 173.6(\mathrm{C}-8)$, two olefinic carbon resonances at $\delta_{\mathrm{C}} 121.7\left(\mathrm{C}-2^{\prime}, 2 "\right)$ and 134.6 (C-3',3"), and two methyl carbon resonances at $\delta_{\mathrm{C}} 17.9\left(\mathrm{C}-4^{\prime}, 4^{\prime \prime}\right)$ and $25.8\left(\mathrm{C}-5^{\prime}, 5^{\prime \prime}\right)$.

The HMBC correlations (Figure 2) were observed between ${ }^{1} \mathrm{H}$ signals at $\delta 3.33$ (H-1',1") and ${ }^{13} \mathrm{C}$ signals at $\delta 126.9$ (C-2,6), 153.4 (C-4), 121.7 (C-2',2”), and 134.6 (C-3',3'), indicating two isopentenyl groups symmetrically substituted to the benzene ring at the positions of C-3 and C-5. Furthermore, the ${ }^{1} \mathrm{H}$ signals at $\delta 4.76$ (H-7) displayed correlations with the ${ }^{13} \mathrm{C}$ signal at $\delta 126.9$ (C-2,6) suggesting that this carbon attached to $\mathrm{C}-1$ of the benzene ring. The long range correlations between the ${ }^{1} \mathrm{H}$ signals at $\delta 3.55(\mathrm{H}-9)$ and ${ }^{13} \mathrm{C}$ signals at $\delta 80.1(\mathrm{C}-7)$ indicated that the ethoxy group was attached to C-7.

Therefore, the structure of $\mathbf{8}$ was proposed as depicted in Fig. 1 and given a trivial name of eurycorymbic acid.

The five known compounds 2-5 and 7 were identified as glucosyringic acid (2) [7], vanillic acid 4-O- $\beta$-D-glucoside (3) [8], koaburaside (4) [9], tachioside (5) [10], and 4-hydroxy-3,5-bis(3-methyl-2-butenyl)benzaldehyde (7) [11] on comparison of their spectral data with literature values. Compounds 2, 3, and 5 were reported for the first time from the family Sapindaceae, and compounds $\mathbf{4}$ and $\mathbf{7}$ were reported for the first time from the genus Eurycorymbus.

The antioxidant activities of compounds 1-6 were evaluated by DPPH free radical scavenging assay. Koaburaside (4) displayed significant scavenging activity with an $\mathrm{IC}_{50}$ of $9.0 \mu \mathrm{M}$; however, tachioside (5) showed weak scavenging activity with $21.51 \%$ of scavenging at a concentration of $16.6 \mu \mathrm{M}$.

The compounds 1-6 were also evaluated for their anti-influenza virus activity by the neuraminidase inhibition assay. Compound $\mathbf{4}$ showed weak inhibitory activity against influenza A neuraminidase with $46.24 \%$ of inhibition at a concentration of $12.0 \mu \mathrm{M}$, but no obviously inhibitory activity was observed for other compounds. 


\section{Experimental}

\subsection{General experimental procedures}

${ }^{1} \mathrm{H}-,{ }^{13} \mathrm{C}$ - and $2 \mathrm{D}-\mathrm{NMR}$ spectra were measured on INOVA-501 spectrometer $\left({ }^{1} \mathrm{H}\right.$ at $500 \mathrm{MHz}$ and ${ }^{13} \mathrm{C}$ at $\left.125 \mathrm{MHz}\right)$ and INOVA-600 spectrometer $\left({ }^{1} \mathrm{H}\right.$ at $600 \mathrm{MHz}$ and ${ }^{13} \mathrm{C}$ at $150 \mathrm{MHz}$ ). Optical rotations were measured using a PERKIN-ELMER 343 digital polarimeter (Norwalk, CT, USA). MS spectrum were recorded on the Agilent 1100 Series LC/MSD Trap spectrometer (APCI-MS), Agilent 6520 Accurate-Mass Q-TOF LC/MS spectrometer (HR-ESI-MS), and Finnigan MAT 95XL mass spectrometer (HR-ESI-MS). Column chromatography (CC) was carried out using D101 macroporous resin (Chemical Plant of Nankai University, Tianjin, China), Diaion HP-20 (Mitsubishi Chemical, Tokyo, Japan), and MCI Gel CHP20P (Supelco, Bellefonte, PA, USA). Semi-preparative HPLC was performed on an Agilent 1100 Series apparatus, equipped with quarternary pump, photodiode array detector, and ChemStation software, using a Grace Alltima C18 column ( $10.0 \times 250 \mathrm{~mm}, 5 \mu \mathrm{m}$, Deerfield, IL, USA).

\subsection{Plant material}

The stem part of Eurycorymbus cavaleriei was collected from the Nanyue Arboretum (Hunan, China) in May 2008, and identified as the stem part of Eurycorymbus cavaleriei by Prof. Ji Zhang, National Institutes for Food and Drug Control. A voucher specimen (No.2008-016) has been deposited at the School of Chinese Medicine, The Chinese University of Hong Kong.

\subsection{Extraction and isolation}

Air-dried stems of E. cavaleriei (5 kg) were extracted with $90 \%$ ethanol. After removing excessive solvent under reduced pressure, the syrup obtained was suspended in water, followed by successive partition with petroleum ether (b.p. 60-80 ${ }^{\circ} \mathrm{C}$, $21.7 \mathrm{~g}$ yield), dichloromethane (36.1 g), ethyl acetate (37.3 g), and $n$-butanol (47.4 g). The $n$-butanol fraction was separated by CC on D101 
macroporous resin (eluted with water, $50 \%$ ethanol and $95 \%$ ethanol successively) to afford three fractions (A-C). Fraction A was further subjected to $\mathrm{CC}$ (MCI Gel CHP20P), eluted with stepwise gradients of water-methanol (100:0, 95:5, 90:10, $85: 15,80: 20,75: 25,70: 30)$ to yield seven sub-fractions (A1- A7). Fraction A2 was purified by semi-preparative HPLC using MeOH-0.1\%TFA (30:70) as mobile phase to afford compounds 1 (2 mg), 2 (5 mg), and 3 (5 mg). Fraction A6 was subjected to CC on Sephadex LH-20 eluted with methanol to yield compound 4 (10 mg). Fraction B was applied to CC on Diaion HP-20 and eluted with stepwise gradients of water-methanol (100:0, 85:15, 70:30, 50:50, 5:95) to give 5 sub-fractions (B1-B5). The fraction B2 was applied to CC on MCI Gel CHP20P and eluted with gradients of water-methanol $(100: 0,95: 5,90: 10,85: 15,80: 20,75: 25,70: 30)$. The seventh fraction (water-methanol 70:30) was purified by semi-preparative HPLC using MeCN-0.1\%TFA (30:70) as mobile phase to yield compounds 5 (10 mg) and 6 (4 $\mathrm{mg})$.

The petroleum ether soluble part of the ethanol extract $(21.7 \mathrm{~g})$ was subjected to CC on silica gel and eluted with stepwise gradients of petroleum ether (b.p. 60-80 ${ }^{\circ} \mathrm{C}$ )-ethyl acetate to give 20 sub-fractions (P1-P20). Fraction P2 was subjected to CC on MCI Gel CHP20P and eluted with gradients of water-methanol to yield compound 7 (20 mg). Fraction P15 was subjected to CC on MCI Gel CHP20P and eluted with gradients of water-methanol to provide ten sub-fractions. The fourth sub-fraction was purified by semi-preparative HPLC with MeOH-0.1\% TFA (75:25) as mobile phase to yield compound $\mathbf{8}(10 \mathrm{mg})$.

\subsubsection{Eurycorymboside A (1)}

White amorphous powder; $[\alpha]_{\mathrm{D}}^{20}-62.1(c=0.17, \mathrm{MeOH})$; UV $\lambda_{\max }^{\mathrm{MeOH}} \mathrm{nm}: 220(\mathrm{sh}), 260$; ${ }^{1} \mathrm{H}-\mathrm{NMR}\left(600 \mathrm{MHz}, \mathrm{CD}_{3} \mathrm{OD}\right)$ and ${ }^{13} \mathrm{C}-\mathrm{NMR}\left(150 \mathrm{MHz}, \mathrm{CD}_{3} \mathrm{OD}\right)$ spectral data: see Table 1; APCI-MS: $m / z 344$ [M+NH$]^{+}$; HR-ESI-MS: $m / z$ 349.0900 [M+Na] ${ }^{+}$(calcd for $\left.\mathrm{C}_{15} \mathrm{H}_{18} \mathrm{O}_{8} \mathrm{Na}, 349.0894\right)$. 


\subsubsection{Eurycorymboside B (6)}

Pale amorphous powder; $[\alpha]_{\mathrm{D}}^{20}-41.3(c=0.31, \mathrm{MeOH})$; UV $\lambda_{\max }^{\mathrm{MeOH}} \mathrm{nm}: 228(\mathrm{sh}), 284$;

${ }^{1} \mathrm{H}-\mathrm{NMR}\left(600 \mathrm{MHz}, \mathrm{CD}_{3} \mathrm{OD}\right)$ and ${ }^{13} \mathrm{C}-\mathrm{NMR}\left(150 \mathrm{MHz}, \mathrm{CD}_{3} \mathrm{OD}\right)$ spectral data: see Table 1; APCI-MS: $m / z 464\left[\mathrm{M}+\mathrm{NH}_{4}\right]^{+}, 447[\mathrm{M}+\mathrm{H}]^{+}$; HR-ESI-MS: $m / z 469.1319$ $[\mathrm{M}+\mathrm{Na}]^{+}$(calcd for $\mathrm{C}_{19} \mathrm{H}_{26} \mathrm{O}_{12} \mathrm{Na}, 469.1316$ ).

\subsubsection{Eurycorymbic acid (8)}

White amorphous powder; $\mathrm{C}_{20} \mathrm{H}_{28} \mathrm{O}_{4} ;[\alpha]_{\mathrm{D}}^{20}-58.5$ (c=0.40, MeOH); UV $\lambda_{\text {max }}^{\text {MeOH }} \mathrm{nm}: 237$ (sh), 280; ${ }^{1} \mathrm{H}-\mathrm{NMR}\left(500 \mathrm{MHz}, \mathrm{CDCl}_{3}\right)$ and ${ }^{13} \mathrm{C}-\mathrm{NMR}\left(125 \mathrm{MHz}, \mathrm{CDCl}_{3}\right)$ spectral data: see Table 1; APCI-MS m/z: 287 [M- $\left.\mathrm{CH}_{3} \mathrm{CH}_{2} \mathrm{OH}+\mathrm{H}\right]^{+}$; HR-ESI-MS (negative): $m / z 331.1994[\mathrm{M}-\mathrm{H}]^{-}$(calcd for $\mathrm{C}_{20} \mathrm{H}_{27} \mathrm{O}_{4}, 331.1988$ ), $286.1576\left[\mathrm{M}-\mathrm{CH}_{3} \mathrm{CH}_{2} \mathrm{OH}\right]^{-}$ (calcd for $\mathrm{C}_{18} \mathrm{H}_{21} \mathrm{O}_{3}, 286.1569$ ).

\subsection{Antioxidant activity}

The DPPH (1,1-diphenyl-2-picrylhydrazyl) assay was carried out according to the modified method of Aquino et al. [12]: the test sample $(10 \mu l)$ at different concentration in DMSO was added into $190 \mu$ of freshly prepared DPPH solution $\left(6.5 \times 10^{-5} \mathrm{M}\right.$, in $\left.\mathrm{MeOH}\right)$. The absorbance of DPPH at $517 \mathrm{~nm}$ was measured on a Zenyth $200 \mathrm{UV}$-Vis spectrophotometer after $30 \mathrm{~min}$. The percentage of scavenging was calculated, and $\mathrm{IC}_{50}$ values were expressed as the concentration of sample required to scavenage $50 \% \mathrm{DPPH}$ free readicals. Vitamin $\mathrm{C}$ was used as positive control, showing an $\mathrm{IC}_{50} 21.1 \mu \mathrm{M}$.

\subsection{Neuraminidase inhibition assay}

The in vitro assay is based on the method reported previously $[13,14]$. The influenza viruses $\mathrm{A} / \mathrm{PR} / 8 / 34(\mathrm{H} 1 \mathrm{~N} 1)$ were used as source of neuraminidase. The enzyme reaction system consisted of $30 \mu \mathrm{l}$ of the enzyme in 33 mM MES buffer ( $\mathrm{pH} 3.5), 10$ $\mu \mathrm{l}$ of $4 \mathrm{mM} \mathrm{CaCl}_{2}, 20 \mu \mathrm{l}$ of $20 \mu \mathrm{M}$ 2'-(4-methylumbelliferyl)- $\alpha$-D-acetylneuraminic acid, $30 \mu \mathrm{l}$ water, and $10 \mu \mathrm{l}$ test solvent in a 96-well microplate. The final volume 
was $100 \mu \mathrm{l}$. After $10 \mathrm{~min}$ incubation at $37^{\circ} \mathrm{C}, 150 \mu \mathrm{l}$ of $14 \mathrm{~mm} \mathrm{NaOH}$ in $83 \%$ ethanol was added to the reaction mixture to terminate the reaction. The intensity of the fluorescence was quantitated in Fluostar Galaxy (excitation, $360 \mathrm{~nm}$; emission, 450 $\mathrm{nm}$ ), and substrate blanks were subtracted from the sample readings. The $\mathrm{IC}_{50}$ was calculated by plotting percent inhibition versus the inhibitor concentration, and determination of each data point was performed in duplicate. Zanamivir was used as positive control, showing an $\mathrm{IC}_{50}$ of $0.72 \mathrm{nM}$. 


\section{References}

[1] China Academy of Science "Floar of China" Editiorial Board, Flora of China (Science Press, Beijing, 1985), Vol. 47(1), p. 66.

[2] L. Cheng, Z.H. Song, P. Zhang, M. Zhang, H.B. Qu, Z.J. Ma, Helv. Chim. Acta. 91, 1659 (2008).

[3] L. Cheng, X.Y. Zhang, M. Zhang, P. Zhang, Z.H. Song, Z.J. Ma, Y.J. Cheng, H.B. Qu, J. Chromatogr. A 1216, 4859 (2009).

[4] Z.J. Ma, X.Y. Zhang, L. Cheng, P. Zhang, Fitoterapia 80, 320 (2009).

[5] Z.J. Ma, X.Y. Zhang, Phytochem. Lett. 2, 152 (2009).

[6] Y. He, M. Zhao, Y.Y. Zong, S.H. Tsai, C.T. Che, Chin. Tradit. Herb. Drugs, 41, 36 (2010).

[7] J. Li, Y. Jiang, P.F. Tu, China J. Chin. Mat. Med. 31, 45 (2006).

[8] A. Sakushima, M. Coskun, T. Maoka, Phytochemistry 40, 257 (1995).

[9] M.I. Chung, M.H. Lai, M.H. Yen, R.R. Wu, C.N. Lin, Phytochemistry 44, 943 (1997).

[10] J. Kitajima, A. Kamoshita, T. Ishikawa, A. Takano, T. Fukuda, S. Isoda, Y. Ida, Chem. Pharm. Bull. 51, 152 (2003).

[11] K. Kyogoku, K. Hatayama, S. Yokomori, T. Seki, I. Tanaka, Agric. Biol. Chem. 39, 133 (1975).

[12] R. Aquino, S. Morelli, M. R. Lauro, S. Abdo, A. Saija, A. Tomaino, J. Nat. Prod. 64, 1019 (2001).

[13] A.L. Liu, H.P. Cao, G.H. Du, Sci. China Ser. C 48, 1 (2005).

[14] J. Zhang, Q. Wang, H. Fang, W.F. Xu, A. Liu, G.H. Du, Bioorg. Med. Chem. 16, 3839 (2008). 
Table 1. ${ }^{1} \mathrm{H}$ - and ${ }^{13} \mathrm{C}$-NMR spectral data of compounds $\mathbf{1}, \mathbf{6}$, and 8 ( $\delta$ in ppm, $J$ in $\left.\mathrm{Hz}\right)$.

\begin{tabular}{|c|c|c|c|c|c|c|}
\hline & \multicolumn{2}{|l|}{$\mathbf{1}^{\mathrm{a}}$} & \multicolumn{2}{|l|}{$6^{\mathrm{a}}$} & \multicolumn{2}{|l|}{$8^{\mathrm{b}}$} \\
\hline & $\delta(\mathrm{H})$ & $\delta(\mathrm{C})$ & $\delta(\mathrm{H})$ & $\delta(\mathrm{C})$ & $\delta(\mathrm{H})$ & $\delta(\mathrm{C})$ \\
\hline 1 & -- & 132.4 & -- & 152.5 & -- & 127.2 \\
\hline 2 & $7.32(\mathrm{~d}, J=9.0)$ & 130.4 & $6.68(\mathrm{~d}, J=3.0)$ & 104.2 & $7.02(\mathrm{~s})$ & 126.9 \\
\hline 3 & $7.02(\mathrm{~d}, J=9.0)$ & 117.2 & -- & 149.2 & -- & 127.5 \\
\hline 4 & -- & 159.0 & -- & 143.2 & -- & 153.4 \\
\hline 5 & $7.02(\mathrm{~d}, J=9.0)$ & 117.2 & $6.65(\mathrm{~d}, J=8.4)$ & 116.0 & -- & 127.5 \\
\hline 6 & $7.32(\mathrm{~d}, J=9.0)$ & 130.4 & $6.51(\mathrm{dd}, J=3.0,8.4)$ & 110.2 & $7.02(\mathrm{~s})$ & 126.9 \\
\hline 7 & -- & 142.7 & $3.78(\mathrm{~s})$ & 56.5 & $4.76(\mathrm{~s})$ & 80.1 \\
\hline 8 & -- & 170.3 & & & -- & 173.6 \\
\hline \multirow[t]{2}{*}{9} & $6.19(\mathrm{~d}, J=1.2)$ & 125.8 & & & $3.55(\mathrm{~m})$ & 65.0 \\
\hline & $5.81(\mathrm{~d}, J=1.2)$ & -- & & & & \\
\hline 10 & & & & & $1.27(\mathrm{t}, J=6.4)$ & 15.0 \\
\hline 1 ' & $4.87(\mathrm{~d}, J=7.8)$ & 102.2 & $4.68(\mathrm{~d}, J=7.2)$ & 103.7 & $3.33(\mathrm{~d}, J=7.0)$ & 29.7 \\
\hline $2^{\prime}$ & $3.40-3,43(\mathrm{~m})$ & 74.9 & $3.30-3.40(\mathrm{~m})$ & 74.9 & $5.30(\mathrm{~m})$ & 121.7 \\
\hline $3{ }^{\prime}$ & $3.40-3.43(\mathrm{~m})$ & 78.0 & $3.30-3.40(\mathrm{~m})$ & 77.8 & -- & 134.6 \\
\hline 4 ' & $3.32-3.35(\mathrm{~m})$ & 71.4 & $3.30-3.40(\mathrm{~m})$ & 71.5 & $1.18(\mathrm{~s})$ & 17.9 \\
\hline 5 & $3.38-3.40(\mathrm{~m})$ & 78.2 & $3.51-3.54(\mathrm{~m})$ & 75.3 & $1.18(\mathrm{~s})$ & 25.8 \\
\hline \multirow[t]{2}{*}{$6^{\prime}$} & $3.83(\mathrm{dd}, J=2.4,12.0)$ & 62.5 & $4.43(\mathrm{dd}, J=1.8,12.0)$ & 64.6 & & \\
\hline & $3.64(\mathrm{dd}, J=5.4,12.0)$ & -- & $4.15(\mathrm{dd}, J=6.0,12.0)$ & -- & & \\
\hline $1 "$ & & & -- & 172.4 & $3.33(\mathrm{~d}, J=7.0)$ & 29.7 \\
\hline $2 "$ & & & $2.60-2.70(\mathrm{~m})$ & 46.3 & $5.30(\mathrm{~m})$ & 121.7 \\
\hline $3 "$ & & & -- & 70.7 & -- & 134.6 \\
\hline $4 "$ & & & $2.50-2.60(\mathrm{~m})$ & 45.8 & $1.18(\mathrm{~s})$ & 17.9 \\
\hline $5 "$ & & & -- & 174.8 & $1.18(\mathrm{~s})$ & 25.8 \\
\hline $6 "$ & & & $1.30(\mathrm{~s})$ & 27.7 & & \\
\hline
\end{tabular}

${ }^{\mathrm{a}}$ Measured in $\mathrm{CD}_{3} \mathrm{OD} .{ }^{\mathrm{b}}$ Measured in $\mathrm{CDCl}_{3}$. 


\section{Figure captions}

Figure 1. Structures of compounds 1, 6, and $\mathbf{8}$ isolated from E. cavaleriei.

Figure 2. Key HMBC $(\mathrm{H} \rightarrow \mathrm{C})$ correlations of compounds 1, 6, and 8. 